\title{
First level seismic microzonation map of Chennai city - a GIS approach
}

\author{
G. P. Ganapathy \\ Centre for Disaster Mitigation and Management, VIT University, Vellore 632 014, Tamil Nadu, India
}

Received: 21 October 2009 - Revised: 30 July 2010 - Accepted: 15 September 2010 - Published: 21 February 2011

\begin{abstract}
Chennai city is the fourth largest metropolis in India, is the focus of economic, social and cultural development and it is the capital of the State of Tamil Nadu. The city has a multi-dimensional growth in development of its infrastructures and population. The area of Chennai has experienced moderate earthquakes in the historical past. Also the Bureau of Indian Standard upgraded the seismic status of Chennai from Low Seismic Hazard (Zone II) to Moderate Seismic Hazard (Zone III)-(BIS: 1893 (2001)). In this connection, a first level seismic microzonation map of Chennai city has been produced with a GIS platform using the themes, viz, Peak Ground Acceleration (PGA), Shear wave velocity at $3 \mathrm{~m}$, Geology, Ground water fluctuation and bed rock depth. The near potential seismic sources were identified from the remote-sensing study and seismo-tectonic details from published literatures. The peak ground acceleration for these seismic sources were estimated based on the attenuation relationship and the maximum PGA for Chennai is $0.176 \mathrm{~g}$. The groundwater fluctuation of the city varies from $0-4 \mathrm{~m}$ below ground level. The depth to bedrock configuration shows trough and ridges in the bedrock topography all over the city. The seismic microzonation analysis involved grid datasets (the discrete datasets from different themes were converted to grids) to compute the final seismic hazard grid through integration and weightage analysis of the source themes. The Chennai city has been classified into three broad zones, viz, High, Moderate and Low Seismic Hazard. The High seismic Hazard concentrated in a few places in the western central part of the city. The moderate hazard areas are oriented in NW-SE direction in the Western part. The southern and eastern part will have low seismic hazard. The result of the study may be used as first-hand
\end{abstract}

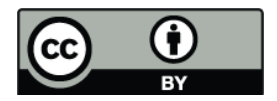

Correspondence to: G. P. Ganapathy (seismogans@yahoo.com) information in selecting the appropriate earthquake resistant features in designing the forthcoming new buildings against seismic ground motion of the city.

\section{Introduction}

Earthquake hazard zonation for urban areas, mostly referred as seismic microzonation, is the first and most important step towards a seismic risk analysis and mitigation strategy in densely populated regions (Slob et al., 2002). As it has been observed from many earthquake scenarios, the major damage to buildings and man-made structures is mostly found in the area of soft sediments (Parvez, 2003). As a result, even relatively minor events can be the source of huge socio-economic disasters. The earthquake of 12 October 1992 with a magnitude of 5.4 in Egypt, where the buildings were not earthquake resistant, resulted in 554 deaths, 20000 people injured with a reported loss of one million US\$ (El-Sayed et al., 2001). It is to be recalled that the present study area (Fig. 1) Chennai city has experienced three earthquakes of magnitudes greater than or equal to 5.0 in 1807,1816 and 1823 . Also the population of the city was 4.343 million in 2001 and projected to 5.343 million in 2011 Census of India (Census, 2001 ${ }^{1}$ ).

Chennai displays various building types of wall materials and their percentage, viz, the earthen walls $(9.59 \%)$ (mud, unbrick, brick), stone walls (3.1\%), burned brick walls $(80.79 \%$ ), concrete walls (Nil), wood and Ekra walls $(0.23 \%)$, GI and other metal sheets $(0.21 \%)$, bamboo thatch, leaves, etc., (6.1\%) (Gupta, 2000). The earthen and stone houses account for $12.59 \%$ and other brittle burned brick are $80.79 \%$, i.e., a total of $93.38 \%$ are vulnerable if shaken by an earthquake of moderate to severe intensity.

\footnotetext{
${ }^{1}$ www.censusindia.com
}

Published by Copernicus Publications on behalf of the European Geosciences Union. 


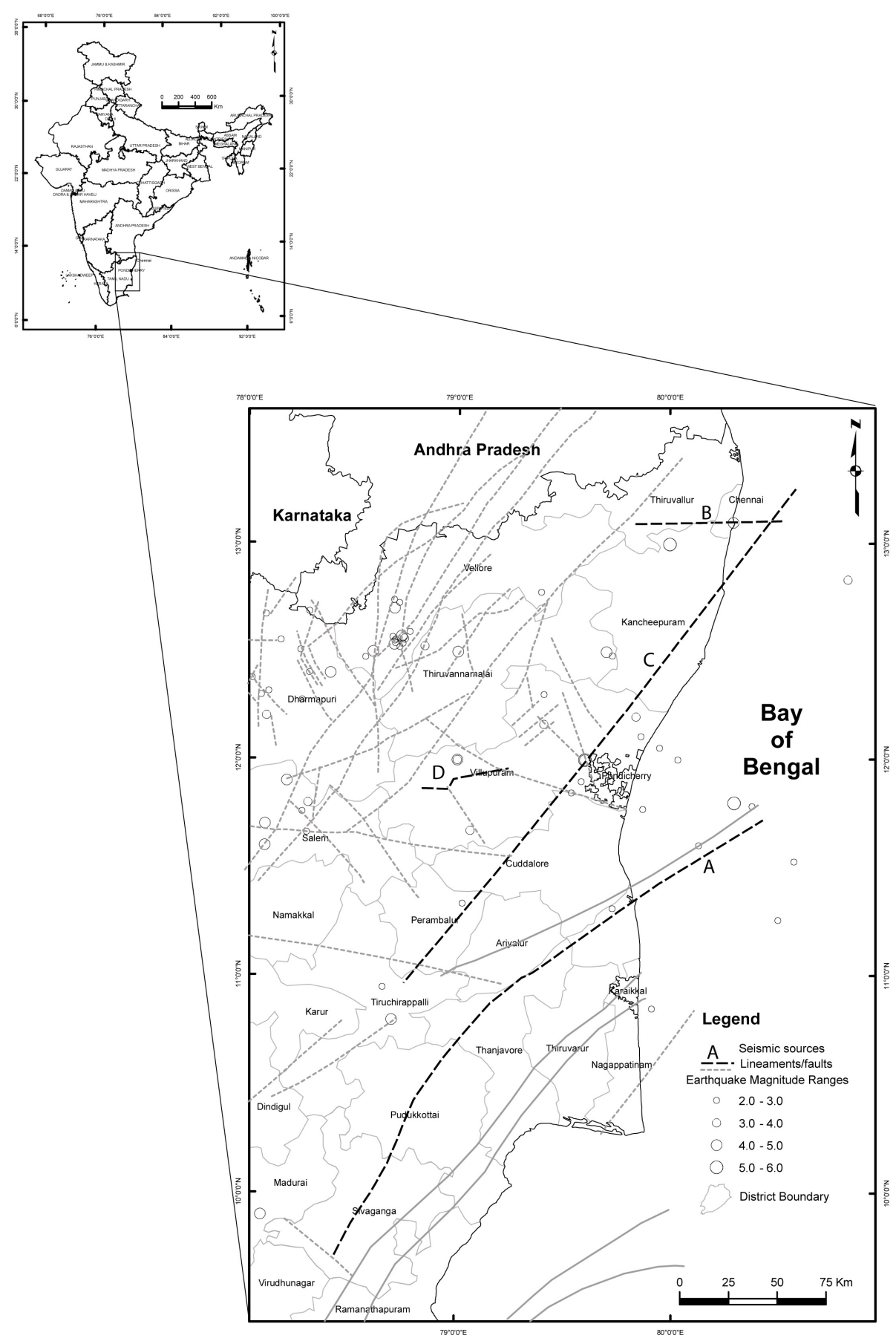

Fig. 1. Seismicity and seismic sources for Chennai city.

A number of water bodies (lakes and ponds), which existed in Chennai in the early period of this century, have been filled up with garbage and transport sand and clay (CGWB Report, 1993). The sand dunes and beach ridges in the coastal belt of Chennai have also been converted into residential areas and as a result, the true landform has been altered. The marshy land existing north of Adyar river has been transformed into a residential area. Buildings constructed in these areas would be highly vulnerable to earthquakes. The water table below the city is shallow and its major part is covered by thick alluvium with a maximum depth of $28 \mathrm{~m}$. This being the case, Chennai is liable for site-specific amplification of seismic motion. Due to its rapid growth in civil construction, industry, etc., a thorough knowledge of the seismicity is needed for adopting mitigation measures. Safety of this city is extremely important for safeguarding human lives and property. This paper aims at producing a first level seismic microzonation map of Chennai city. 


\section{Data used}

The geological, ground motion, seismotectonic features and ground water conditions are the input to assess the seismic hazard for Chennai. The involved baseline data are discussed in the following headings.

\subsection{Peak Ground Acceleration (PGA)}

A seismicity study is of great importance to understand the dynamic behaviour of the earth and is useful to determine the earthquake hazard in a specific region. In order to understand the seismicity of Chennai and its vicinity, data regarding spatial locations of earthquakes and their magnitudes have been collected for a period of around 200 years (1807-2006) from various sources and have been used for the present study. For the historical earthquakes general locations are used for which "generalized" epicentral co-ordinates are available. The total number of earthquakes identified from these sources for the present study is 103 . Out of the total 103 earthquakes/earth tremors 48,23,21, 10 and 1 incidences have been in the magnitude range of 2.0-2.9, 3.0-3.9, 4.0 $4.9,5.0-5.9$ and $\geq 6.0$, respectively. 52 earthquakes $(51 \%$ of overall) are of $M \geq 3$ in the past 200 years of seismic history (Ganapathy, 2005).

Analysis of tectonic lineaments and faults helps in understanding the regional seismotectonic activity of the area. For the present study, seismotectonic details are collected from the report published by Central Ground Water Board, Chennai. The NE-SW trending Archaean boundary fault is located in Chennai and separates two basins. The southern one is shallow without Gondwana sediments. The northern basin has extensive Gondwana sediments beneath the alluvium. The presence of bedding joints, shears and microfolding in core samples are indicative of the extensive tectonic disturbance in the post-Gondwana period. The Adyar fault is shown in Fig. 1 and this weak zone is followed by the flow of the Adyar river.

The potential seismic sources delineated based on the geophysical and geological characteristics of the seismic sources along with the prevailing fault systems in the region. The association of the cumulative number of epicentres of earthquakes or higher magnitude earthquakes on the respective active lineaments/faults has also been considered. Based on the seismicity and seismogenic systems, 4 sources have been delineated as potential sources for Chennai city and its vicinity of a $200 \mathrm{~km}$ radius. These seismic potential sources are named based on its spatial locations. These sources generated earthquakes in the range of 3.2 to 5.3 in the past earthquake history of 200 years. In the present study, the largest well recorded earthquakes which occurred in the instrumental time period are taken into consideration. The estimation of ground motion in terms of PGA at bedrock level can be determined using attenuation relationships. A variation of this approach uses the reference and site recordings as for their
Table 1. Estimated Peak Ground Acceleration (PGA) values Chennai city by the closest potential seismic sources.

\begin{tabular}{lllll}
\hline $\begin{array}{l}\text { Seismic } \\
\text { Sources }\end{array}$ & $\begin{array}{l}\text { Cumulative } \\
\text { Earthquakes }\end{array}$ & $\begin{array}{l}\text { Maximum } \\
\text { Magnitude }\end{array}$ & $\begin{array}{l}\text { Epicentral } \\
\text { Distance } \\
\text { from } \\
\text { Chennai }\end{array}$ & $\begin{array}{l}\text { Estimated } \\
\text { Peak } \\
\text { Ground } \\
\text { Acceleration }\end{array}$ \\
& & & & \\
\hline A & 5 & 5.6 & 156 & 0.176 \\
B & 1 & 5.3 & 10 & 0.107 \\
C & 3 & 5.0 & 155 & 0.078 \\
D & 3 & 5.0 & 174 & 0.078 \\
\hline
\end{tabular}

different site-source distances. This was done using ratios of hypocentral distance by Borcherdt and Glassmoyer (1994). Distance corrections incorporating frequency-dependent attenuation have been implemented by Borcherdt (2001).

For the regions where strong motion data are not available for such analysis, the attenuation relationships developed for other regions can be used based on the resemblance of the seismotectonic characteristics of both the regions. Abrahamson and Litehiser (1989) have proposed an attenuation model for Peak Ground Acceleration (PGA) based on 585 strong ground motion records from 76 worldwide earthquakes. A suitable attenuation relationship developed by Iyengar and Raghukanth (2004) for Peninsular India applicable to Chennai is used for the present study. The attenuation relation used to calculate PGA is given below:

$\ln y=c 1+c 2(M-6)+c 3(M-6)^{2}-\ln R-c 4 R+\ln €$

Where $y$ refers to PGA in $\mathrm{g}, M$ refer to magnitude and $R$ refer to hypocentral distance. Since PGA is known to be attributed nearly as a lognormal random variable $\ln y$ would normally distributed with the average of $(\ln \Theta)$ being almost zero. Hence, with $e=I$, coefficients for the southern region are (Iyengar and Raghukanth, 2004):

$c 1=1.7816 ; c 2=0.9205 ; c 3=-0.0673 ; c 4=0.0035$;

$(\ln €)=0.3136($ taken as zero $)$

The determined PGA for the four identified potential seismic sources for the city of Chennai is in the range of $0.176 \mathrm{~g}$ to 0.078 (Table 1). The maximum PGA of 0.176 would be caused by the east-west trending in the southern part of Chennai (Fig. 2). This fault has been associated with 4 earthquake incidences in the past 200-year earthquake history and the maximum magnitude $\left(M_{\max }\right)$ so far generated is 5.3.

\subsection{Shear wave velocity from geotechnical data}

Chennai city has many multi-storey buildings and these buildings have been constructed based on geotechnical studies through Standard Penetration Tests (SPT). 503 borehole data have been obtained from various geotechnical agencies 


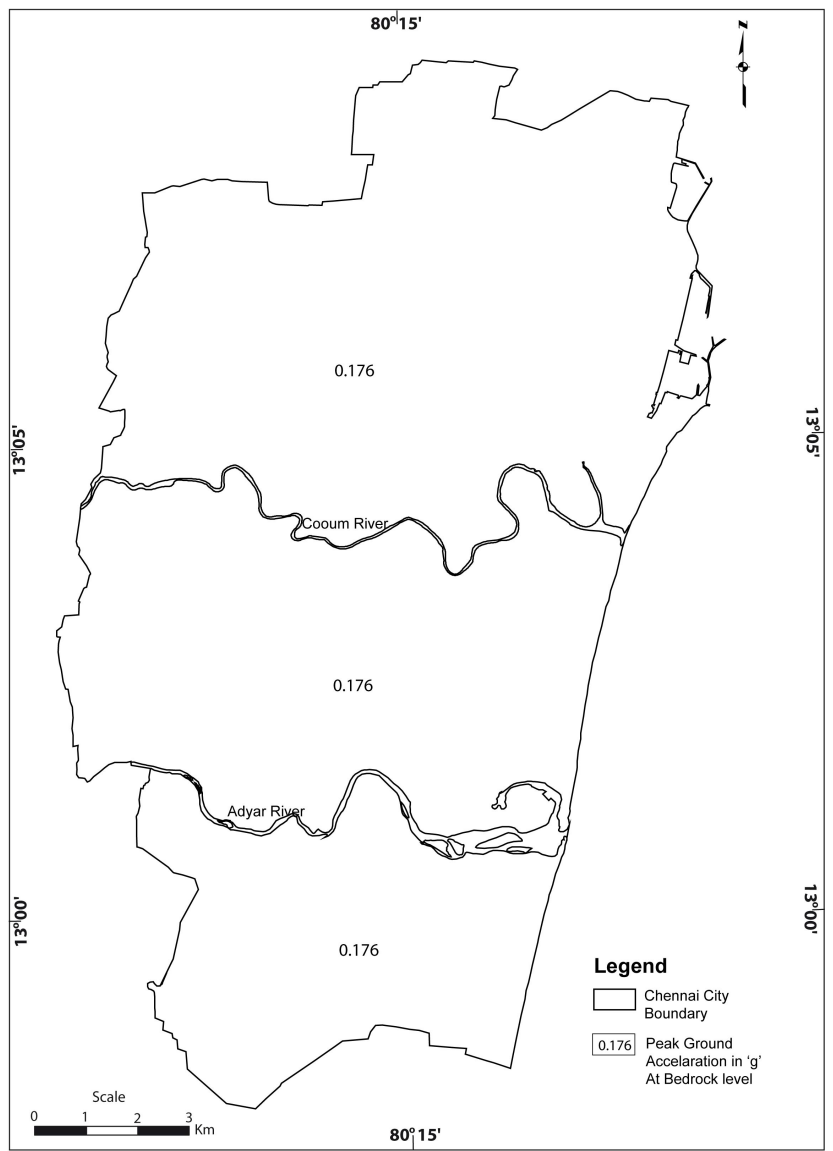

Fig. 2. Estimated peak ground acceleration for Chennai city.

including SPT-N values, and various characteristics of soils in depths. The borehole locations are given in Fig. 3. The depth of the boreholes is in the range of 2.0 to $32 \mathrm{~m}$. Only 43 boreholes are penetrated down to basement. The "N" values observed in the field, using the standard penetration test equipment, and the standard test procedure were corrected for (a) overburden stress, (b) hammer energy, (c) borehole diameter, (d) rod length, and (e) presence or absence of liner.

Based upon the distribution of "N" values in different depths, the average SPT-N value contour maps were prepared for a $3 \mathrm{~m}$ depth. The relative density of sand and clay is categorized based on the SPT-N values (Terzaghi and Peck, 1967) details are related with shear wave velocity and it is given in Table 2.

The shear wave velocity is an important parameter to assess the strength of the soil. Soil profiles are characterised by shear wave velocity because it is a key indicator of soil susceptibility. Shear wave velocity can be estimated from correlations with the Standard Penetration Test (SPT), water content and soil type. Researchers developing empirical attenuation relations have attempted to use site classification based on average shear wave velocity to account for the differences in site response (Boore and Joyner, 1982). The re-
Table 2. "N" value $V_{\mathrm{S}}$ shear wave velocity.

\begin{tabular}{ccc}
\hline $\begin{array}{c}\text { "N"Value } \\
\text { Relative } \\
\begin{array}{c}\text { Density } \\
\text { of Sand }\end{array}\end{array}$ & $\begin{array}{c}\text { "N"Value } \\
\text { Relative } \\
\text { Density } \\
\text { of Clay }\end{array}$ & $\begin{array}{c}\text { Shear } \\
\text { Wave } \\
\text { Velocity }\end{array}$ \\
\hline$<4$ & $<2$ & $<50$ \\
$4-10$ & $2-8$ & $50-130$ \\
$10-30$ & $8-15$ & $130-165$ \\
$30-50$ & $15-30$ & $165-185$ \\
$>50$ & $>30$ & $185-350$ \\
\hline
\end{tabular}

sult of average shear wave velocity have been obtained for Chennai for the depth of $0-3 \mathrm{~m}$ by using the empirical relationships proposed by Imai and Yoshimura (1970) - Eq. (2), Ohba and Goto (1978) - Eq. (2).

$V_{\mathrm{S}}=76 N^{0.33}$

$V_{\mathrm{S}}=84 N^{0.31}$

Where $V_{\mathrm{S}}=$ average shear wave velocity in $\mathrm{ms}^{-1}$ and $N=$ average SPT "N" value. The contours of average shear wave velocity at a $3 \mathrm{~m}$ depth is prepared by using Arc-GIS Spatial Analyst software by Interpolating Raster by Inverse distance weighted method and presented in Fig. 4.

\subsection{Geology}

The Archaean crystalline rocks, Gondwana and Tertiary sediments and Recent alluvium are the three group of geological formations found in Chennai. Most of the geological formations are concealed since they are overlain by the alluvial materials except for a few exposures of crystalline rocks of charnockites (Fig. 5) in the southwestern part of Chennai (CGWB Report, 1993).

The Archaean crystalline rocks of the city comprise chiefly of charnockites, gneisses and the associated basic and ultrabasic intrusives. The charnockites represent the major rock type in the area of Saidapet. The crystalline rocks are weathered and jointed/fractured. The degree and depth of weathering varies from place to place and the thickness of the weathered mantle varies from less than $1 \mathrm{~m}$ to about $12 \mathrm{~m}$ in the city.

The Gondwana shale is exposed in Adyar river near Ramavaram (southern part of Chennai). The GondwanaArchaean contact is a fault concealed by alluvium. The Gondwana shale is black to dark grey in colour and highly jointed/fractured. The shale is encountered in a number of boreholes and its thickness varies from $24 \mathrm{~m}$ in Kilpauk, area through $20 \mathrm{~m}$ in Ashok Nagar area to more than $139 \mathrm{~m}$ in Koyambedu area.

The Tertiary sandstones are reddish brown to grayish white and white in colour, friable and mottled. The occurrence of the Tertiary in Chennai is not well demarcated. 


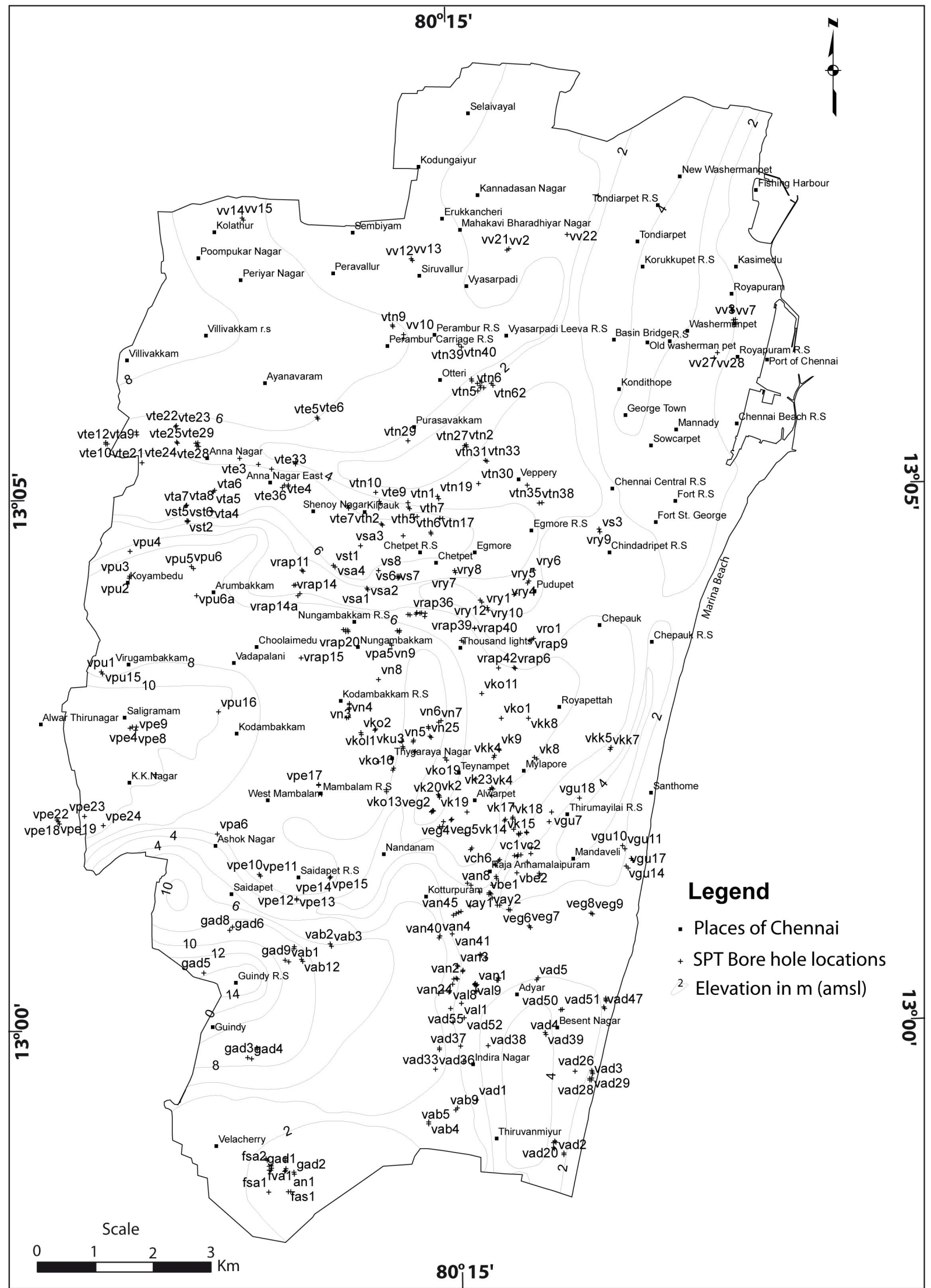

Fig. 3. Location of boreholes used for the geotechnical analysis. 


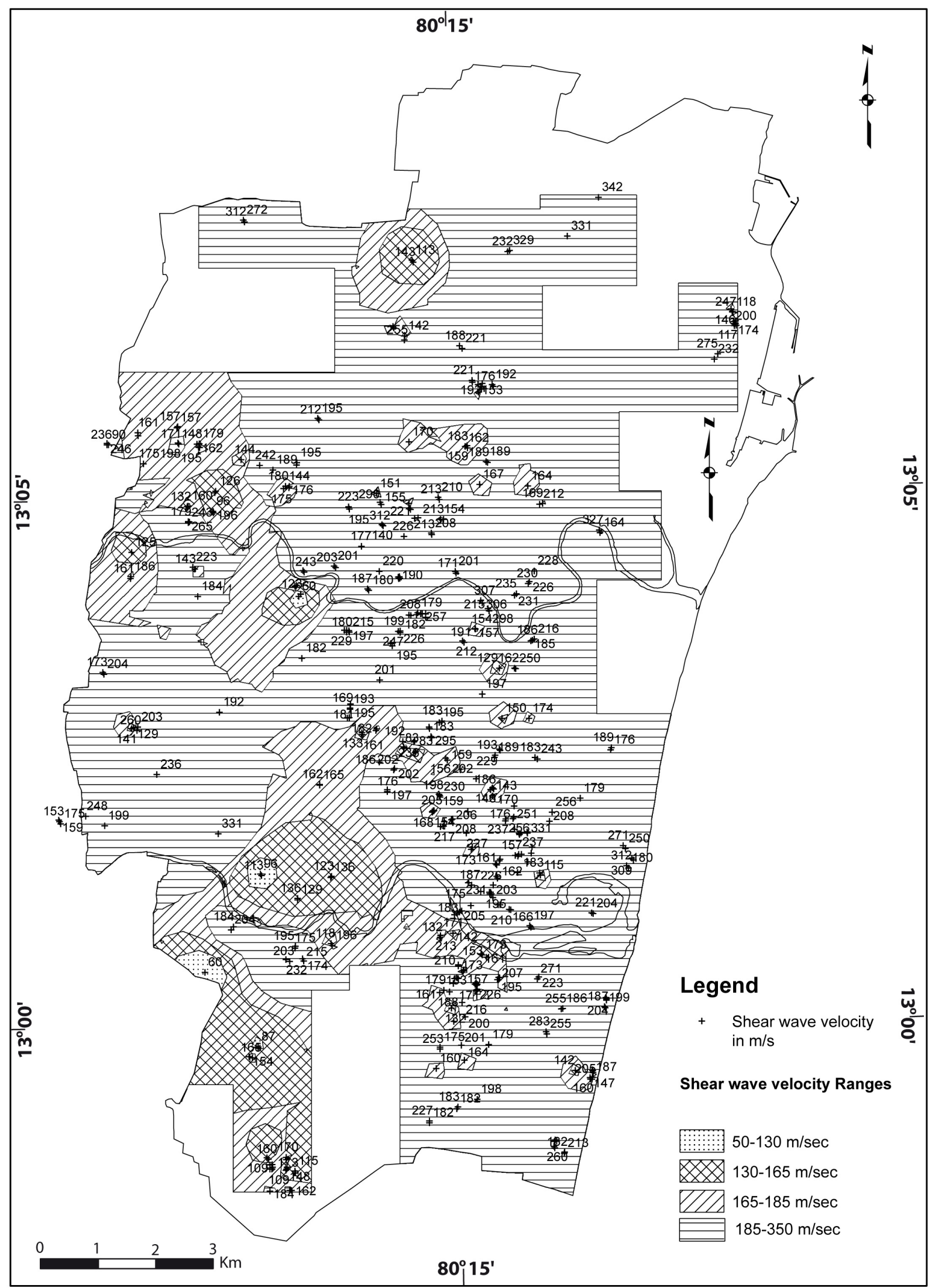

Fig. 4. Estimated shear wave velocity at $3 \mathrm{~m}$ depth. 


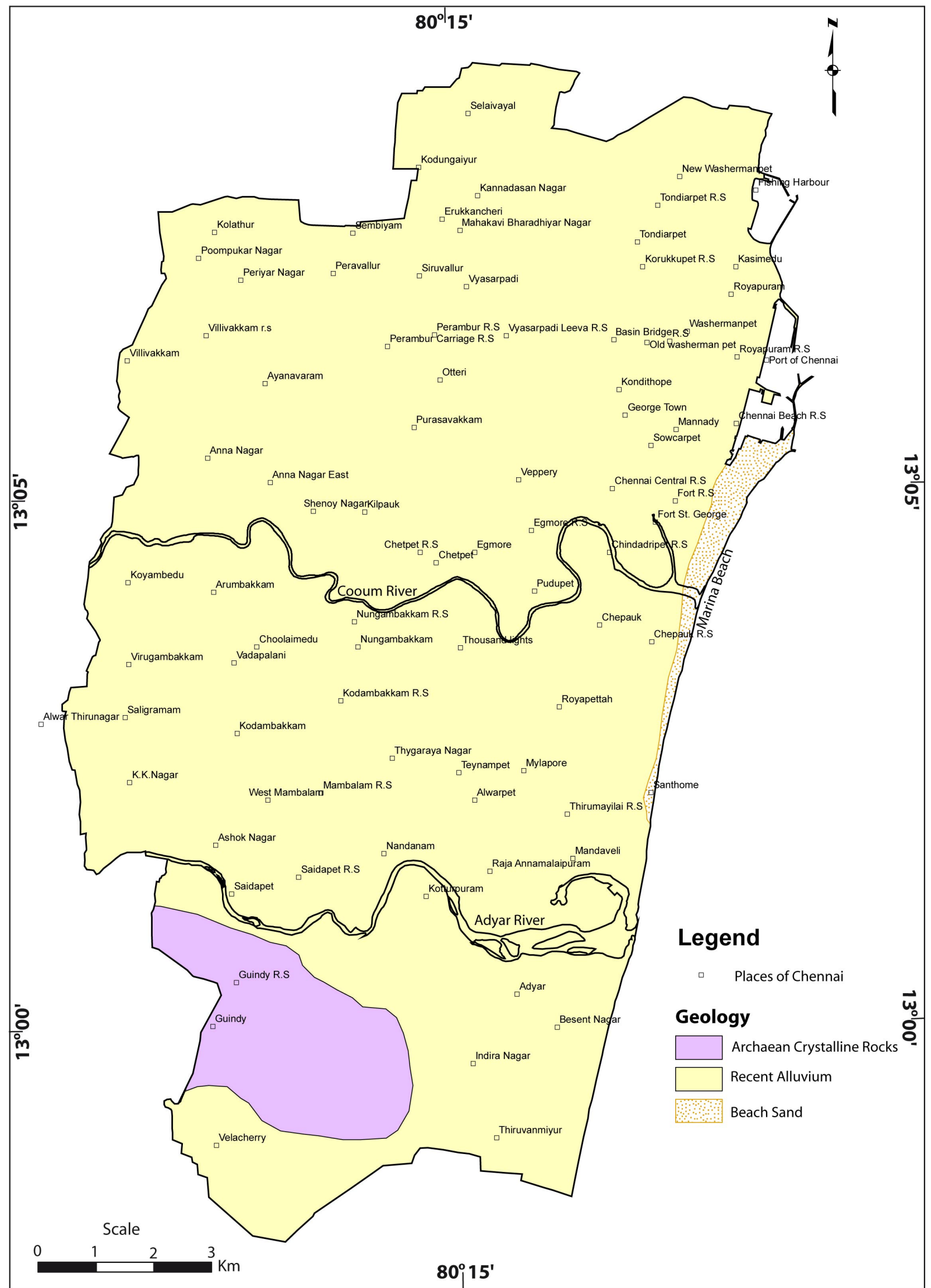

Fig. 5. Geology of Chennai city. 


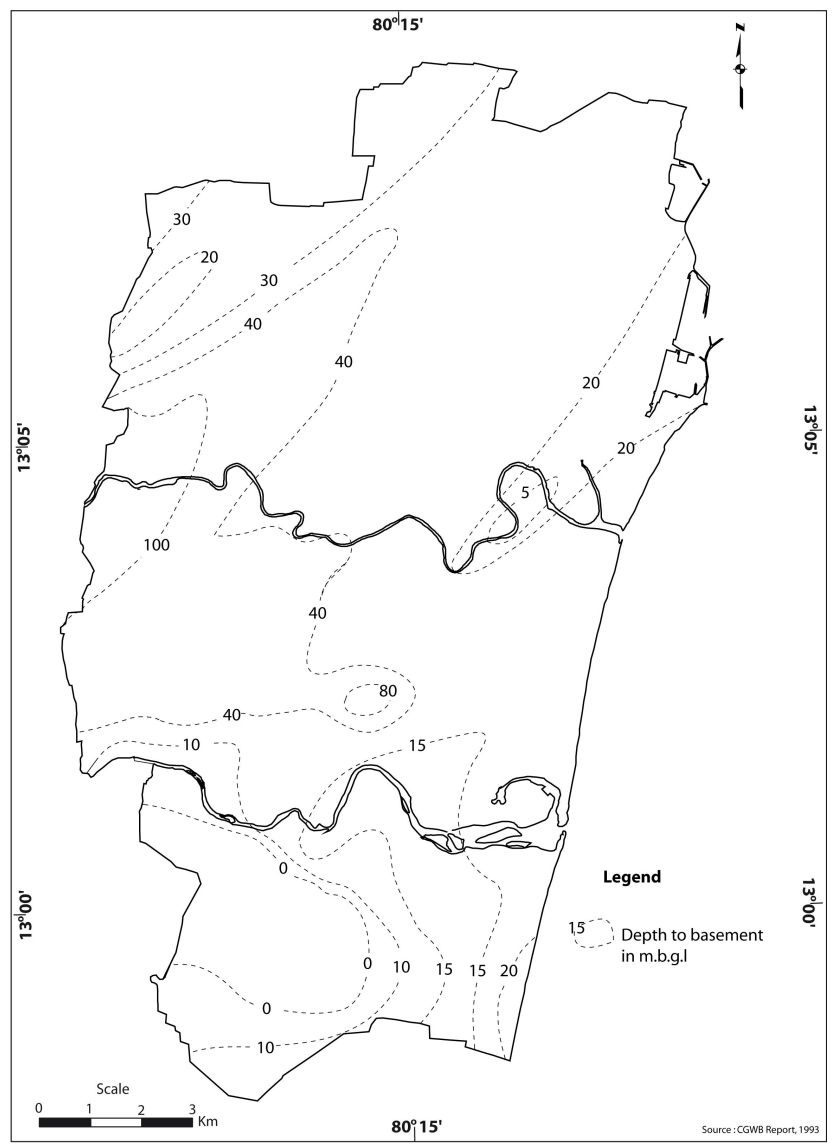

Fig. 6. Map showing the depth to basement of rock at Chennai city.

However, the sandstones encountered in some of the boreholes below alluvium in Perambur, Alwarpet, Anna Nagar and Royapuram areas are different from the compact dark coloured shale of Gondwana Group and they may belong to the Tertiary. Probably Tertiary rocks are deposited on the eroded Gondwana System and are overlain by river alluvium.

The alluvium covers the major part of Chennai. It consists of sand, silts and clays. The thickness of alluvium varies from place to place and a maximum of $28 \mathrm{~m}$ is encountered in drilled boreholes of north Chennai near Perambur.

\subsection{Depth to bedrock}

Borehole data are the only reliable data to estimate the depth to bedrock, which is an important key parameter in assessing the soil column thickness over it. The bedrock configuration of a site will give an idea about the basement topography. The basement topography will help in the study of frequencies and amplitudes of ground motions. This will help to identify high (as well as low) seismic risk areas from the point-of-view of wave propagation influence.

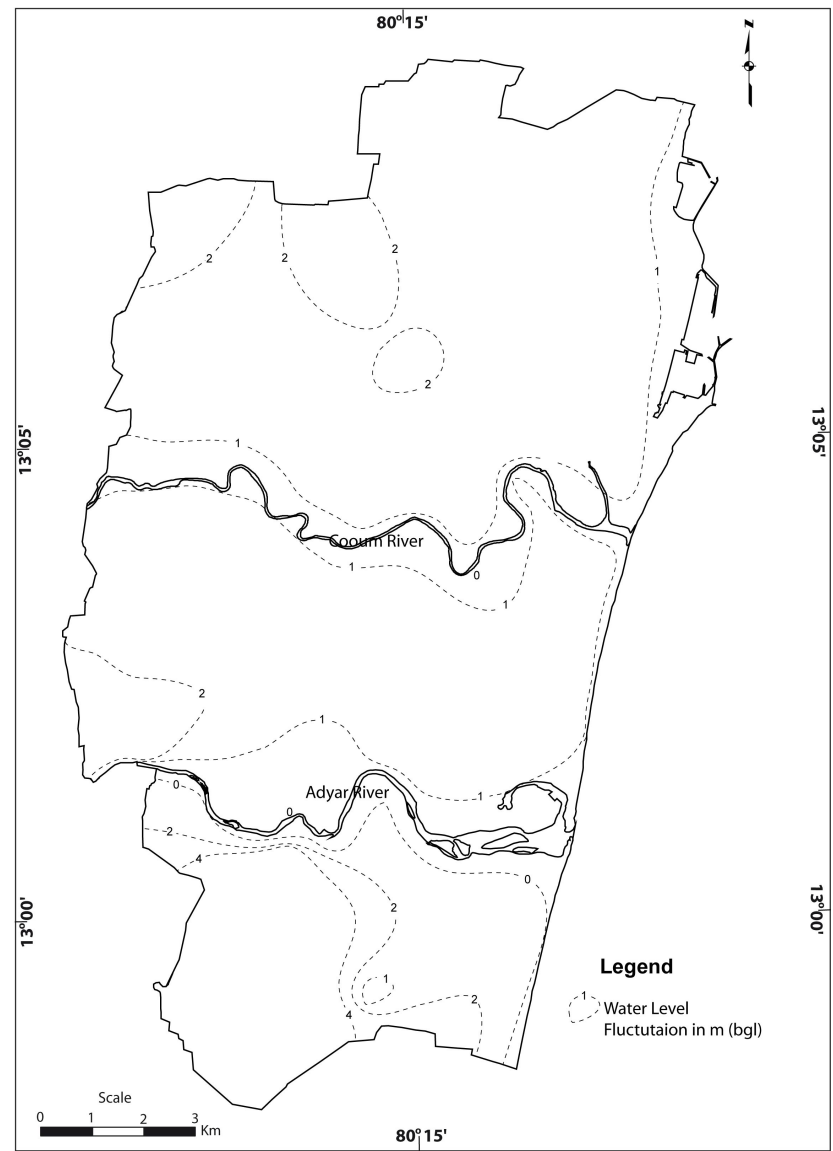

Fig. 7. Map showing the water level fluctuation at Chennai city.

The basement is somewhat shallow in the southern side of crystalline basement near Saidapet and Guindy Park (0 $5 \mathrm{~m})$. The basement is relatively high in the northern part of the city $(20-40 \mathrm{~m})$. The western Central part of the city had a very high basement depth of $40-80 \mathrm{~m}$. The generalised basement contour map needs to be refined with the forthcoming of more and more data. The sub-surface geology and basement configuration is presented in Fig. 6.

\subsection{Depth to water table and water level fluctuation}

The depth of water level and water-level fluctuation contours are presented in Fig. 7. This ranges between 1.15 and $0.93 \mathrm{~m}$ b.g.l. where as it is shallow in the range of 0.15 and $5.63 \mathrm{~m}$ b.g.l. in post-monsoon period. It can be seen that the water table generally follows the topography with gentle slopes towards the rivers as well as the sea. The water table elevation varies from $3.5 \mathrm{~m}$ a.m.s.l. to $2.2 \mathrm{~m}$ b.m.s.l. The fluctuation is high in selected stations like Besant Nagar and Aminjikarai, an indication of higher draft in selected pockets. 
Table 3. Assigned weights for the thematic maps for GIS integration.

\begin{tabular}{lllllll}
\hline Themes & PGA & Soil & Geology & $\begin{array}{l}\text { Ground } \\
\text { Water }\end{array}$ & Bedrock & Weightage \\
\hline PGA & 1 & $5 / 4$ & $5 / 3$ & $5 / 2$ & $5 / 1$ & 0.3333 \\
Shear Wave Velocity & $4 / 5$ & 1 & $4 / 3$ & $4 / 2$ & $4 / 1$ & 0.2666 \\
Geology & $3 / 5$ & $3 / 4$ & 1 & $3 / 2$ & $3 / 1$ & 0.2000 \\
Ground Water & $2 / 5$ & $2 / 4$ & $2 / 3$ & 1 & $2 / 1$ & 0.1333 \\
Bedrock & $1 / 5$ & $1 / 4$ & $1 / 3$ & $1 / 2$ & 1 & 0.0666 \\
\hline
\end{tabular}

Table 4. Normalised ratings of the thematic layers.

\begin{tabular}{lccccc}
\hline Themes & Weightage & \multicolumn{4}{c}{ Normalised Values } \\
\cline { 3 - 6 } & & 4 & 3 & 2 & 1 \\
\hline PGA (in g) & 0.3333 & - & 0.176 & - & - \\
Shear Wave Velocity $\left(\mathrm{m} \mathrm{s}^{-1}\right)$ & 0.2666 & $50-130$ & $130-165$ & $165-185$ & $185-350$ \\
Geology & 0.2000 & - & Alluvium & Beach Sand & Rock \\
Ground Water Fluctuation (m) & 0.1333 & $0-2$ & $2-4$ & - & - \\
Bedrock (m) & 0.0666 & $>40$ & $20-40$ & $10-20$ & $0-5$ \\
\hline
\end{tabular}

\section{Approach}

There are a variety of subjective decision rules and the most commonly used one being the analytic hierarchy process (AHP) of Saaty (1980) and weighted linear combination (WLC) (Barredo et al., 2000; Ayalew and Yamagishi, 2004; Ayalew et al., 2004). The analysis has been carried out following Saaty's Analytical Hierarchy Process (AHP). Analytic Hierarchy Process (AHP) is one of a Multi-Criteria decision making method that was originally developed by Thomas L. Saaty. In short, it is a method to derive ratio scales from paired comparisons. It uses hierarchical structures to quantify relative priorities for a given set of elements on a ratio scale, which is based on the discernment of the user. From the judgments between two particular elements, a pair wise comparison matrix is constructed on a scale of $1-5,1$ indicating that the two elements are equally important, and 5 implying that one element is more important than the other. If an element is less significant than the other then it is indicated by reciprocals of $1-5$ values (i.e., $1 / 1$ to $1 / 5$ ). The pair wise comparison matrix prepared is used to derive the individual normalized weights of each element. The weights of each criterion are calculated by averaging the values of each row of the matrix. The Consistency Ratio, which is a comparison between Consistency Index and Random Consistency Index, obtained using AHP method is $8.3 \%$. These weights also add up to 1 and can be used in deriving the weighted sums of rating for each region of polygons of the mapped layers. This approach has also been successfully used by Mohanty et al. (2007) for the similar type of microzonation studies.
The features of each thematic map are also normalized between 0 and 1 (Nath, 2004) to ensure that no layer exerts an influence beyond its determined weight. The weightage factor of each layer calculated is based on expert choice. For the study, the paired comparison matrix is prepared for the five themes (PGA contour, soil, geology, groundwater fluctuation and bedrock depth) as shown in Table 3. Following the AHP, the thematic maps are assigned weights on a scale of 1-5 depending on their contribution to seismic hazard. The higher weight is assigned to the theme that contributes more to the hazard and in this case the highest weight is given to the PGA contour theme. The weights obtained for each theme are: PGA (0.333), Shear wave Velocity (0.266), geology (0.20), groundwater $(0.133)$ and bedrock depth (0.066). The normalized ratings for thematic layers are given in Table 4 . The feature of each themes normalised between 0 and 1 .

The obtained values are then incorporated in a GIS platform for the integration of all the thematic maps to obtain the seismic microzonation map of Chennai city. The integration of five thematic layers is integrated by the UNION and overlay operation in GIS.

\section{Discussions and conclusion}

Chennai has been broadly classified into three zones, as high, moderate and low in terms of seismic hazard in an event of future earthquakes. Part of Chennai falls in seismically moderate to high hazard prone areas (Fig. 8). The resultant map depicts that the high hazard areas are distributed 


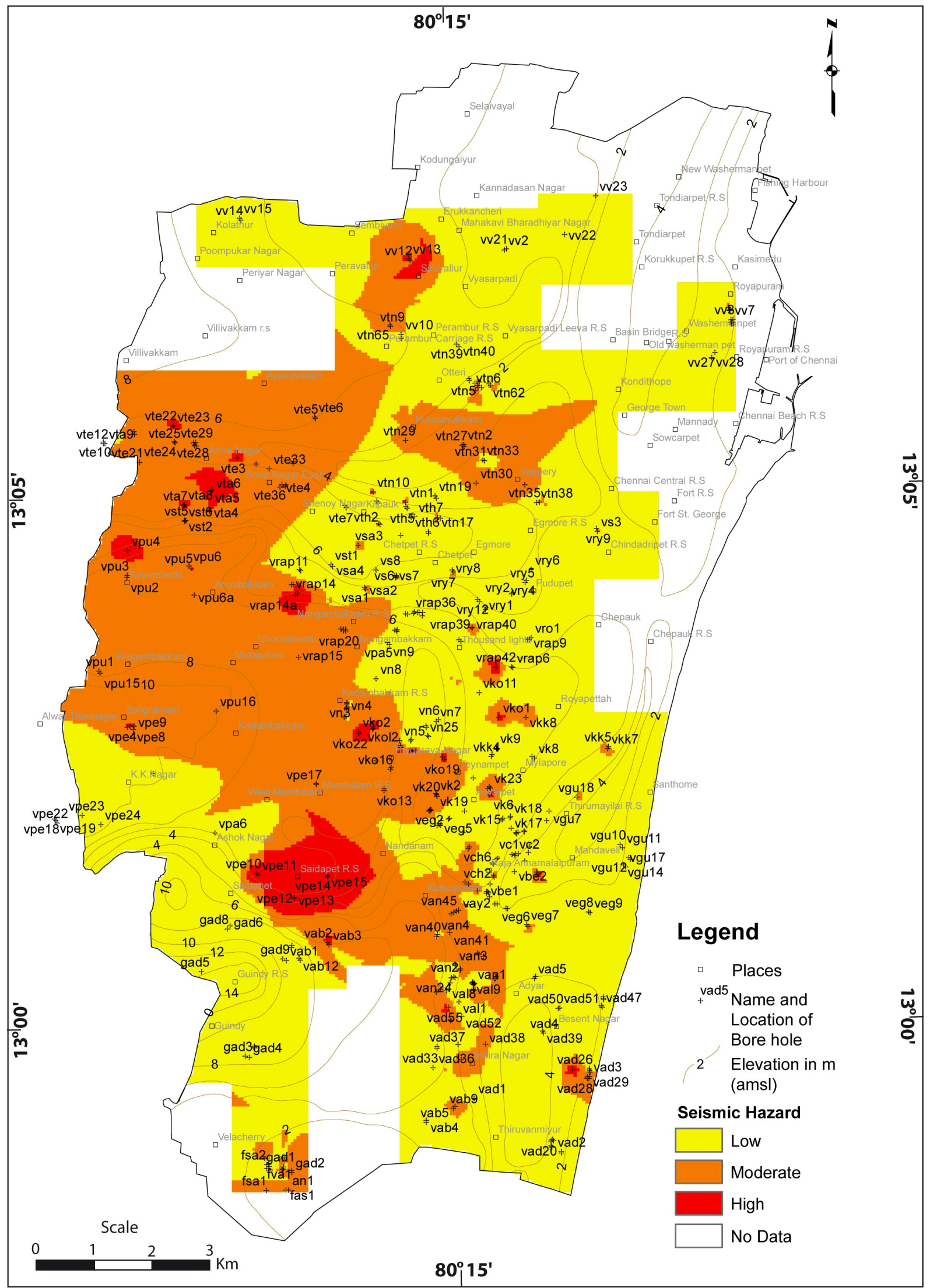

Fig. 8. First level seismic microzonation map of Chennai city. 
in patches around Adyar River and few patches distributed below Cooum River in the south western part of the city. The areas in the southern part of Chennai represent lacustrine deposits is underlined by marine black clay as evident in Taramani areas. The maximum depth to basement is $14 \mathrm{~m}$. The central part of the city has mainly fluvial origin of flood plain deposits as evidence from the flowing Adyar and Cooum rivers. The upstream portion of Adyar and Cooum rivers have a moderate slope and in the down stream, the rivers are very gentle to flat in coastal areas. These areas in the northern part of the city represent black clay and alluvium of marine origin with maximum depth to basement of $30 \mathrm{~m}$ and patches of these areas show high hazard. The western and northwestern part of Chennai falls under moderate hazard. These areas represent the shale and clay of the Gondwana age and are also correlated with lake fill deposits. The remaining areas are prone to low seismic hazard. It can be concluded that the half of the Chennai city is prone to moderate to high hazard. The resultant map provides regional pictures on seismic hazard of Chennai city and is useful information in construction planning of forthcoming buildings in the city. Also it is helpful as a base material to identify seismic risk of Chennai city.

Acknowledgements. The author is grateful to the Central Ground Water Board, Chennai and Geological Survey of India, Chennai for providing the data and necessary information without which this work would not have been possible. I acknowledge all the facilities provided by G. Viswanathan, Chancellor, VIT University, Vellore to carryout second part of the present study. The constant encouragement by R. K. Bhandari, Former Chairman, and S. K. Sekar, Director, CDMM, VIT University, Vellore and S. Rajarathnam, Professor, Centre for Disaster Mitigation and Management, Anna University, Chennai are gratefully acknowledged.

Edited by: M. E. Contadakis

Reviewed by: R. Carbonell, J. Papoulia, and D. Papanastasiou

\section{References}

Abrahamson, N. A. and Litehiser, J. J.: Attenuation of Vertical Peak Acceleration, B. Seismol. Soc. Am., 79, 549-580, 1989.

Ayalew, L. and Yamagishi, H.: Slope movements in the Blue Nile basin, as seen from landscape evolution perspective, Geomorphology, 57(1-2), 95-116, 2004.

Ayalew, L., Yamagishi, H., and Ugawa, N.: Landslide susceptibility mapping using GIS-based weighted linear combination, the case in Tsugawa area of Agano River, Niigata Prefecture, Japan, Landslides, 1(1), 73-81, 2004.

Barredo, J. I., Benavidesz, A., Herhl, J., and van Westen, C. J.: Comparing heuristic landslide hazard assessment techniques using GIS in the Tirajana basin, Gran Canaria Island, Spain, Int. J. Appl. Earth Obs., 2(1), 9-23, 2000.
BIS: 1893: Indian Standard, Criteria for Earthquake Resistant Design of Structures, Bureau of Indian Standards, New Delhi, 2001.

Boore, D. M. and Joyner, W. B.: The empirical prediction of ground motion, B. Seismol. Soc. Am., 72, S43-S60, 1982.

Borcherdt, R. D: Empirical Evidence for Acceleration-Dependent Amplification Factors, B. Seismol. Soc. Am., 92, 761-782, 2001.

Borcherdt, R. D. and Glassmoyer, G.: Influences of Local Geology on Strong and Weak Ground Motions Recorded in the San Francisco Bay Region and their Implications for Site-Specific Building-Code Provisions, The Loma Prieta, California Earthquake of October 17, 1989 - Strong Ground Motion, US Geol. Surv. Prof. Paper, 1551-A, A77-A108, 1994.

CGWB Report: Groundwater Resources and Development Prospects in Madras District, Tamil Nadu, Central Ground Water Board, Southern Region, Hyderabad, 1993.

El-Sayed, A., Vaccari, F., and Panz, G. F.: Deterministic seismic hazard in Egypt, Geophys. J. Int., 144, 555-567, 2001.

Ganapathy, G. P.: Seismic Hazard Assessment for Tamil Nadu State and A Specific Study on Local Ground Motion Response for Part of Chennai City, Anna University, Ph.D. thesis, unpublished, 2005.

Gupta, T. N.: Guidelines - Improving Earthquake Resistance of Housing, published by: Building Materials and Technology Promotion Council, New Delhi, 2000.

Imai, T. and Yoshimura, Y.: Elastic Wave Velocity and Soil Properties in Soft Soil Tsuchi-to-Kiso, 18(1), 17-22, 1970.

Iyengar, R. N. and Ragukanth, S. T. G.: Attenuation strong ground Motion in Peninsular India, Seismol. Res. Lett., 75(4), 530-540, 2004.

Mohanty, W. K., Walling, M. Y., Nath, S. K., and Pal, I.: First Order Seismic Microzonation of Delhi, India Using Geographic Information System (GIS), Nat. Hazards, 40, 245-260, 2007.

Nath, S. K.: Seismic Hazard Mapping in Sikkim Himalaya through GIS Integration of Site Effects and Strong Ground Motion Attributes, Nat. Hazards, 31(2), 319-342, 2004.

Ohba, Y. and Goto, N.: Empirical shear wave velocity equations in terms of characteristics soil indexes, Earthq. Eng. Struct. D., 6, 167-187, 1978.

Parvez, I. A.: Seismic Microzonation: Methodology and Approach, CSIR Centre for Mathematical Modelling and computer Simulation, Bangalore, Research Report, 14 pp., 2003.

Saaty, T. L.: The Analytical Hierarchy Process, McGraw Hill, New York, 350 pp., 1980.

Slob, S., Hack, R., Scarpas, T., van Bemmelen, B., Duque, A.: A Methodology for Seismic Microzonation Using GIS and Shake, A Case Study from Armenia, Colombia, Engineering Geology for Developing Countries - Proceedings of 9th Congress of the International Association for Engineering Geology and Environment Durban, South Africa, 16-20 September 2002, edited by: van Rooy, J. L. and Jermy, C. A., 2843-2852, 2002.

Terzaghi, K. and Peck, R. B.: Soil Mechanics in Engineering Practice, 2nd edn., John Wiley \& Sons, New York, 729 pp., 1967. 